\title{
Macrofaunal modification of porewater advection: role of species function, species interaction, and kinetics
}

\author{
George G. Waldbusser*, Roberta L. Marinelli \\ Chesapeake Biological Laboratory, One Williams Street, PO Box 38, Solomons, Maryland 20688, USA
}

\begin{abstract}
Sedimentary habitats are complex associations of biotic, chemical, and physical processes comprising 'ecosystem function'. The relative importance of these processes to biogeochemical cycling in highly reactive, permeable sediments remains poorly understood. We report results from several field experiments in a muddy-sand intertidal flat dominated by 2 functionally different types of bioturbating macrofauna in False Bay, Washington, USA: (1) the arenicolid polychaete Abarenicola pacifica and (2) 2 species of thalassinid shrimp (Upogebia pugettensis and Neotrypaea californiensis). Experimental plots composed primarily of one of the study taxa or mixed communities of both were evaluated for their effects on porewater advection, solute concentrations, and sediment characteristics. Fluorescein-impregnated acrylamide gels were used to infer rates of transport, and acrylamide gel peepers were used to record porewater concentrations of diagenetically important constituents among experimental plots. Laboratory studies evaluated rates of diffusive transport in non-bioturbated sediments for comparative analysis. We found that (1) functionally different macrofauna affect rates of porewater advection in permeable sediments, (2) organism effects are not attributable to changes in average measures of sediment granulometry, (3) species interactions may further complicate the advective environment and the resulting diagenetic processes, and (4) species effects vary according to reaction rate kinetics. We hypothesize that species-related effects on transport are due to inhibition of arenicolid feeding by thalassinid tubes that serve to block sediment fluidization and advective flow. Thus, specific behaviors and interactions among organisms appear to affect transport rates and sediment function in advectively permeable habitats. The results indicate the importance of integrating behavior, kinetics, and transport into future studies of sedimentary biodiversity and ecosystem function.
\end{abstract}

KEY WORDS: Species interaction · Porewater advection · Arenicolid · Thalassinid · Biogeochemistry

\section{INTRODUCTION}

Marine sedimentary systems are complex associations of biological, chemical, and physical processes that operate on varying spatial and temporal scales. From these collective elements, ecosystem function emerges. The difficulty in understanding intermediate- and smallscale process complexity of coastal sedimentary systems arises, in part, from current limitations in our characterization of macro-organism interactions with physical and biogeochemical processes (Marinelli \& Waldbusser 2005). Studies increasingly point to the importance of species-related differences in activity rates (Boudreau \& Marinelli 1994) and density-dependent processes (Marinelli \& Williams 2003, Lohrer et al. 2004) that create geochemical variability with fundamental ecological significance. For example, keystone species such as urchins or maldanid polychaetes that alter local community structure and small-scale sediment geochemistry have broad-scale effects on ecosystem function when integrated over larger scales (Levin et al. 1997, Widdicombe \& Austen 1998, Waldbusser et al. 2004). The diagenetic setting, dictated by rates of organic input and internal geochemical cycling (Canfield et al. 1993a,b, 
Thamdrup et al. 1994, Jahnke \& Jahnke 2000), is an additional element of complexity that co-determines the outcome of ecosystem processes (Kristensen et al. 1985). Lastly, physical-biological interactions related to boundary layer dynamics affect interfacial processes (Eckman 1983, Huettel et al. 1998), with significant implications for resource utilization (Taghon et al. 1980), population dynamics (Eckman 1996), and sedimentseawater exchange (Jahnke et al. 2000). Given the diversity of processes and potential interactions among them, identification of mechanisms that alter system function is crucial to developing predictable relationships between ecosystem structure and function (Levin et al. 2001).

It is increasingly clear that consideration of the geochemical milieu helps elucidate the mechanisms by which biodiversity alters system function. For example, Waldbusser et al. (2004) found that biodiversity effects associated with lower than predicted phosphate fluxes (underyielding) were largely explained by depthintegrated oxygen concentrations within the sediment and the effect of oxygen on phosphate adsorption. This relationship was driven by the presence of 1 active deepdwelling organism in the experimental treatments and, therefore, may be considered a selection effect (Wardle 1999). The extensive literature on diagenetic and other sedimentary processes may readily provide explanatory mechanisms for many of the effects found in biodiversity and ecosystem function studies of sediments. Ongoing debate regarding the nature of biodiversity effects (Kinzing et al. 2001) and lack of congruity among conclusions from sediment-diversity experiments (Emmerson et al. 2001, Bolam et al. 2002, Biles et al. 2003) point to the need for a more integrated and thorough investigation of sediment dynamics.

Concurrent with the expansion of biodiversity research in benthic environments has been the increased recognition of permeable sediments (and associated porewater advective flows) as habitats of significant and rapid biogeochemical cycling. As Rocha (2000) argues, the basis for modern diagenetic research has focused on non-permeable sediments, with diffusion and bioirrigation as the primary transport mechanisms. Extant bioirrigation models have successfully captured average geochemical environments inhabited by organisms in diffusive sediments (Guinasso \& Schink 1975, Aller 1980, Boudreau 1984). However, these models generally are not suited to permeable sedimentary habitats due to assumptions regarding diffusive transport around organism burrows. A common assumption regarding advectively dominated environments is the erasing of chemical potential gradients generated by organism burrows, and therefore a dampening or lack of sedimentary organism effects. Rather, the primary importance of infauna in permeable sediments are as creators of topographic features and associated pressure gradients that, in turn, drive advective flow (Huettel \& Webster 2001, but see D'Andrea et al. 2002, 2004 for counter examples). Furthermore, de Beer et al. (2005) estimated roughly $25 \%$ of the exchange between sediment and overlying water on an advective intertidal sand flat was due to bioturbational activities of infauna, emphasizing the potential importance these communities may have on geochemical cycling in permeable sediments. Although recent findings indicate the importance of infauna on sedimentary processes in permeable sediments, it is critical to biodiversity/ecosystem function research that we understand whether functionally different species and interactions among them create ecologically significant variance in permeable sediment processes.

In the current study, we conduct several field experiments in a muddy-sand intertidal flat dominated by 3 species of 2 functionally different bioturbating macrofauna, consider the complexity associated with nondiffusion-dominated environments, and discuss the implications for biodiversity/ecosystem studies in terms of species interactions. Our questions in this study are as follows: (1) Do 2 functionally different bioturbating infauna have different effects on sedimentary processes in this permeable sedimentary habitat? (2) Does the interaction between the 2 functional types affect the transport of porewater and solute distributions? (3) What are the possible mechanisms for any organism effects found on sediment dynamics? (4) What are the implications for the future of biodiversity and ecosystem function research within permeable sediments, as well as in other habitats?

\section{MATERIALS AND METHODS}

Site and organisms. This study was conducted in False Bay, Washington, USA (latitude $=48.488^{\circ}$, longitude $=-123.065^{\circ}$ ), an intertidal flat approximately $1 \mathrm{~km}^{2}$ in area during maximum exposure, located on San Juan Island. The tides are mixed semi-diurnal, with a maximum tidal range of $4 \mathrm{~m}$ and daily exposure times of nearly $12 \mathrm{~h}$ during late spring and summer, imparting considerable temperature fluctuations of overlying water and within the sediment (G. G. Waldbusser unpubl. data). The sediment column in the study area was underlain by an impermeable clay layer roughly $30 \mathrm{~cm}$ beneath the sediment surface. All experiments were conducted at the $+1 \mathrm{~m}$ tidal height (from mean low water).

The study area is relatively pristine and has a diverse infauna, including errant (e.g. nereidid and glycerid polychaetes) and relatively sedentary species (e.g. the bivalve Macoma sp. and lumbrinereid polychaetes). 
However, the dominant taxa are the lugworm Abarenicola pacifica and 2 species of thalassinid shrimp, Upogebia pugettensis and Neotrypaea californiensis. Maximum densities of surface features, a proxy for organism density, were roughly 75 fecal mounds or burrow openings $\mathrm{m}^{-2}$ for arenicolid and thalassinid taxa, respectively (Krager \& Woodin 1993, our Table 1). No differentiation could be made between the thalassinid species without destructive sampling, and therefore they are treated as 1 taxonomic unit.

The arenicolid and thalassinids are characterized by differences in feeding mode and burrowing. Abarenicola pacifica is a head-down deposit feeder with a body length of up to $10 \mathrm{~cm}$. It maintains a mucus-lined, $\mathrm{j}$-shaped tube and feeds indirectly on surface material by fluidizing the sediment above the feeding area at the tube base and subducting surface material downward. Taghon (1988) measured fecal production rates of up to $280 \mathrm{~d}^{-1}$ (grams of sediment to grams of ash-free dry weight worm per day) for A. pacifica. A significant body of literature exists on the ecology of arenicolids, and the reader is directed to Hobson (1967), Brenchley (1981), Riisgård \& Banta (1998), Linton \& Taghon (2000), and references therein for further information. The presence and abundance of A. pacifica can be verified by characteristic fecal mounds found on the sediment surface next to its well-formed tail shaft (Krager \& Woodin 1993).

In contrast, thalassinid species create large subsurface galleries with $\geq 1$ openings to the sediment surface (Nickell \& Atkinson 1995). They excavate large volumes of sediment, often suspending fine particles, increasing turbidity of the overlying water, and negatively affecting other organisms (MacGinite 1930, Suchanek 1983, Posey et al. 1991, Pinn et al. 1998, Feldman et al. 2000). Both Upogebia pugettensis and Neotrypaea californiensis are obligate burrow dwellers, and are considered to be facultative suspension and deposit feeders, respectively (Posey et al. 1991). Further, differences in reproduction and lifehistory strategies seem to allow these sympatric species to co-occur (Dumbauld et al. 1996, Coelho et al. 2000, and references therein).

Experimental plots of areas dominated by the arenicolid, thalassinids, and mixed communities were identified in mid-June and maintained until the end of August. Three $0.5 \times 0.5 \mathrm{~m}$ plots within 3 larger blocks were selected by visual inspection of the sediment surface for features characteristic of each taxon. All plots within a block were within 1 to $2 \mathrm{~m}$ of each other, and blocks were $\sim 50$ to $100 \mathrm{~m}$ apart and at similar tidal heights. Plots were designated as (1) arenicolid dominated, (2) thalassinid dominated, or (3) mixed communities of the 2 taxa. At 3 intervals over the field season, a series of daily photographs were taken at low tide
(23 to 25 June, 19 to 22 July, and 4 to 7 August) to verify these designations and the persistence of the organisms. Photographic image data, used to estimate the abundances of arenicolids and thalassinids by surface features, were analyzed using Image-J software.

Advection and diffusion measurements. The potential importance of advective porewater movement within the experimental area was evaluated using a conservative tracer, fluorescein, released from an acrylamide gel diffuser over an outgoing and incoming tide. A $20 \%$ acrylamide gel plug $(2.54 \mathrm{~cm}$ diameter, $5 \mathrm{~cm}$ length), containing $1 \mathrm{mg} \mathrm{ml}^{-1}$ fluorescein was made according to Browne \& Zimmer (2001). A $1 \mathrm{~m}$ transect line was established parallel to the long axis of the bay, on a sand bar with a gradual slope, within a site that appeared to lack any obvious surface features that would indicate the presence of large bioturbating infauna. At 12:00 $\mathrm{h}$ the gel was inserted (via core replacement) into the middle of the transect with the center of the gel roughly at $5 \mathrm{~cm}$ depth. The gel was then covered with sediment such that the surface was flush with the surrounding area. Starting at 12:45 h and every subsequent hour, a small volume $(\sim 1 \mathrm{ml})$ of porewater was taken at $5 \mathrm{~cm}$ depth, along both directions of the linear transect, at 3 locations: 1,3 , and $5 \mathrm{~cm}$ from the gel. The sample was obtained by inserting a canula, attached to a syringe, to the $5 \mathrm{~cm}$ depth interval and gently withdrawing fluid at depth. The last sample was taken at $18: 30 \mathrm{~h}_{\text {; }}$ this was the time the incoming tide had begun to cover the experimental area. We assumed that the major axis of flow would be horizontal, based on the pressure gradient generated by the retention and drainage of porewater within the sediments, though some vertical transport probably occurred. Upon retrieval, all samples were filtered through a $0.45 \mu \mathrm{m}$ filter and placed in a dark cooler until analysis on a Turner-Quantech fluorometer. The acrylamide gel plug was left in the sediment for $3 \mathrm{~d}$ before retrieval on 26 May 2004, when the porewater sampling was repeated, as above.

To evaluate the relative magnitude of advective versus diffusive transport in these sediments, a laboratory experiment was conducted to measure tracer movement in a diffusion-dominated environment. Since diffusive transport is the sum of random non-directional Brownian movements resulting in transport down a gradient, the vertical or horizontal orientation of the experimental set up is irrelevant on this spatial scale, and thus measures of vertical diffusion in a controlled experiment can be compared to measures of advective transport measured in situ in a horizontal direction. A PVC pipe $10 \mathrm{~cm}$ in diameter and $30 \mathrm{~cm}$ long was capped on the bottom, outfitted with a vertical line of sampling ports drilled at $1.5 \mathrm{~cm}$ intervals to a height of $15 \mathrm{~cm}$, and fitted with rubber septa as described in 
Marinelli et al. (1998). A $20 \%$ acrylamide solution with $1 \mathrm{mg} \mathrm{ml}^{-1}$ fluorescein was made, poured into the bottom of the PVC pipe, and allowed to polymerize. Sediment from the study site was collected, mixed, and defaunated by allowing the mixture to go anoxic for 2 wk. Once defaunated, the sediment was carefully added to the pipe to a depth of roughly $10 \mathrm{~cm}$ on 9 July 2004 (Day 0). The diffusion experiment was kept at constant room temperature, and did not reflect the temperature variability found at the site. Temperature changes of surface sediments due to solar heating were roughly $10^{\circ} \mathrm{C}$ at the field site (G. G. Waldbusser unpubl. data). Using the Wilke-Chang formula to calculate the temperature dependence of changes in the diffusion coefficient of fluorescein (Browne \& Zimmer 2001), the free solution diffusion coefficient varied by $0.1 \times 10^{-6} \mathrm{~cm} \mathrm{~s}^{-1}$, with a $10^{\circ} \mathrm{C}$ temperature change from 10 to $20^{\circ} \mathrm{C}$. Thus, the consequence of not mimicking field temperatures on diffusive transport is minimal. Porewater samples ( 1 to $2 \mathrm{ml}$ ) were taken on Days 10, 18 , and 25, filtered, and analyzed for fluorescein concentration immediately, as described above.

Fluorescein-loss experiments. To assess differences in rates of porewater advection between plots dominated by functionally different fauna, we deployed acrylamide gels infused with fluorescein in the experimental plots, described above. The fluorescein concentrations remaining in the gels after a given period of time acted as a proxy for relative rates of porewater advection. We hypothesized that gels in areas of higher advective flows would lose fluorescein faster due to the increased flushing of the surrounding sediment.

Acrylamide plugs (1.1 cm diameter, $9 \mathrm{~cm}$ length) were made with a $15 \%$ gel (Browne \& Zimmer 2001, as above) containing $1 \mathrm{mg} \mathrm{ml}^{-1}$ fluorescein. After polymerization, the gels were removed from the cylinders and wrapped individually in a single layer of No. 75 Nitex mesh. On 19 July 2004, 5 replicate gels were deployed in each experimental plot (described above), $10 \mathrm{~cm}$ apart along a $0.5 \mathrm{~m}$ transect perpendicular to the axis of advective flow measured previously. The gels were retrieved on 21 July 2004 by taking a $5 \mathrm{~cm}$ diameter sediment core around the plug and then breaking apart the core to obtain the gel plug. Excess sediment was gently wiped from the exterior, and two $5 \mathrm{~mm}$ subsections of the plug were taken roughly $\sim 1 \mathrm{~cm}$ from each end of the plug. The subsections were placed in pre-weighed sample vials and covered with foil to prevent photo-degradation of fluorescein within the gels. Immediately upon returning from the field, the sample vials were reweighed, and $2.5 \mathrm{ml}$ of deionized (DI) water was added to each vial for backequilibration of fluorescein out of the gel and into solution. The samples were placed on a shaker table in the dark for $48 \mathrm{~h}$. The fluorescein concentration in the back-equilibrated water was then determined via fluorometry, and the fluorescein remaining in the gel was corrected based on the dilution factor and the volume of the acrylamide.

Sediment porewater solutes. Porewater peepers, containing acrylamide gels as solute recorders (modified from Hesslein 1976, Mortimer et al. 1999), were used to measure depth profiles of ammonium, phosphate, silicate, alkalinity, and $\mathrm{pH}$ at the study site and to evaluate the effects of biologically modified porewater flow on sediment biogeochemistry. Each peeper had 10 wells $(0.75 \mathrm{~cm}$ deep by $3.2 \mathrm{~cm}$ wide by $8 \mathrm{~mm}$ high) of approximately $2 \mathrm{ml}$ in volume, allowing the measurement of a $10 \mathrm{~cm}$ profile from $1 \mathrm{~cm}$ below the sediment surface to $11 \mathrm{~cm}$ depth. To each well, $2 \mathrm{ml}$ of a $15 \%$ acrylamide gel was added. Gels were made with potassium persulfate as an initiator rather than ammonium persulfate, to avoid ammonium contamination (Engstrom \& Marinelli 2005). After polymerization, the peeper wells were covered with $0.45 \mu \mathrm{m}$ Magna nylon filter paper and were prehydrated in $30 \mathrm{psu}$ $\mathrm{NaCl}$ solution for $5 \mathrm{~d}$ prior to deployment in the field on 4 August 2004. Peepers were deployed in the same experimental plots used to measure fluorescein loss, but $11 \mathrm{~d}$ after these experiments were concluded. Three replicate peepers were deployed in each plot within all 3 blocks, with the narrow edge facing the dominant axis of flow. Peepers were retrieved on 10 August 2004 (6 d deployment), wiped clean of sediment, placed in plastic bags, and refrigerated. Subsequently, the individual gels from each depth interval were removed using clean stainless steel spatulas and latex gloves and placed in $15 \mathrm{ml}$ sterile centrifuge tubes containing $8 \mathrm{ml}$ of DI water. For back-equilibration, tubes were placed in the dark on a shaker table in a cold room at $10^{\circ} \mathrm{C}$ for $48 \mathrm{~h}$. Solutes and $\mathrm{pH}$ were then measured on the back-equilibrated solution and corrected for the dilution. Random checks of salinity on the back-equilibrated water were done to detect possible evapo-concentration of solutes within the gels, either in the course of handling or during deployment in the field.

Calculations were made to verify the response time of the gels to changes in surrounding porewater concentrations. Using free solution diffusion coefficients for ammonium, phosphate, and silicate (Boudreau 1997), the acrylamide-specific diffusion coefficients were calculated and Bessel series summations were performed as in Browne \& Zimmer (2001). Roughly $10 \%$ or less of the solute would be present in the gel (75 mm diffusion length based on well depth) after $1 \mathrm{~d}$ of equilibration, if exposed to solute-free water. In other words, it would take roughly $24 \mathrm{~h}$ for the gel to equilibrate to within $90 \%$ of surrounding concentra- 
tions, if those concentrations were constant. Integrating the temporal variability associated with the tidal draining and saturation of these sediments requires extended sampling. We estimated that a deployment time of $6 \mathrm{~d}$ would be sufficient to allow for the gels to accurately record average porewater values; this was true based on prior measures of sediment porewater constituents using direct extraction (G. G. Waldbusser unpubl. data). Therefore, gels successfully integrated temporal variability in porewater constituents over the deployment period.

Chemical analyses. Analyses of ammonium, phosphate, silicate, and alkalinity were performed on a Smartchem discrete chemical analyzer (Westco Scientific). Ammonium was analyzed using a modification of the phenol method as outlined by Koroleff (1976). Phosphate analysis followed a modification of the Environmental Protection Agency's (EPA) Method 365.2 and Eaton et al. (1995). Silicate was analyzed according to Strickland \& Parsons (1972). Alkalinity was determined using the methyl orange method (EPA 310.2). Dissolved inorganic carbon was calculated from the $\mathrm{pH}$ and alkalinity measures by dissociation constants using a MATLAB routine (csys.m and equic.m) developed by R. E. Zeebe and D. A. Wolf-Gladrow (www.awi-bremerhaven.de/Carbon/co2book.html). The measurement of $\mathrm{pH}$ was conducted using a $\mathrm{pH}$ electrode and meter (VWR Scientific Model 8000).

Sediment parameters and measured permeability. Grain size analysis was conducted on composite samples from each experimental plot using standard sieving techniques and graphical analysis of the cumulative percent distributions following Folk \& Ward (1957). Three $3 \mathrm{~cm}$ diameter cores of roughly $7 \mathrm{~cm}$ depth were taken from each plot and were combined to obtain a composite sample of each plot on 14 August 2004. Composite samples were weighed, dried, and reweighed to calculate porosity [volume pore water/ volume (sediment + porewater)]. A value of $2.65 \mathrm{~g} \mathrm{ml}^{-1}$ was used to correct for the density of quartz, and $1.023 \mathrm{~g} \mathrm{ml}^{-1}$, for seawater in the calculations. Permeability was calculated by the Rumpf-Gupte equation (Boudreau 1997) using grain size and porosity measures. Sediment organic carbon and nitrogen were determined for three $1 \mathrm{~cm}$ diameter surface cores (0.5 to $1.0 \mathrm{~cm}$ depth) taken in each plot using a Carlo Erba-440 elemental analyzer.

As an independent permeability measure, 1 intact sediment core $(5.08 \mathrm{~cm}$ diameter by $\sim 10 \mathrm{~cm}$ high sediment column) was taken in the middle of each plot within 1 of the 3 blocks and returned to the laboratory. These cores lacked obvious surface features that would indicate the presence of large bioturbating infauna. Permeability of these intact cores was determined using the falling-head permeameter method (Gray 1958). The measured permeability is based on the actual velocity of porewater movement through an intact sediment core (given a certain pressure head), whereas the calculated permeability uses theoretical considerations and empirically derived relationships between porosity and grain size (Boudreau 1997).

Data analysis. Porewater profiles were depthintegrated using trapezoidal integration. A 2-way ANOVA, with treatment, block, and treatment $\times$ block interaction effects, was used to analyze differences in fluorescein-loss and integrated porewater data as a function of the dominant taxon/treatment (arenicolid, thalassinids, or mixed). The fluorescein-loss and integrated porewater data were transformed to meet the assumptions of normality and homogeneity of variance in the ANOVA tests as follows: fluoresceinloss data and porewater data were natural log transformed, and organism abundance data were square root transformed. When no block effect was found, the block effect was dropped from the model, and data were reanalyzed as a 1-way ANOVA. A TukeyKramer correction was used on the individual Student's $t$-tests of treatment differences. Statistically determined outlier values were found and removed from the fluorescein-loss analysis in 3 observations of the thalassinid treatment and 1 observation of the mixed treatment. All statistical analyses were conducted using SAS Version 8.

Two types of post hoc exploratory regression analyses were conducted to investigate possible density dependence and interaction effects of these 2 species on variability in sediment porewater constituents. In the analyses, the abundance data obtained from the August photographs were averaged over the $3 \mathrm{~d}$ period. The chemistry data ( 3 replicates plot $^{-1}$ ) were not averaged for each experimental plot, in order to reflect spatial variability of porewater within each plot. The original treatment assignments of arenicolid, thalassinid, and mixed were ignored, and the densities of each organism within all plots were regressed against the porewater solute concentrations. We acknowledge the observations are not independent, but point to 2 reasons why such a method may be appropriate in this exploratory analysis. First, there is a lack of straightforward statistical analysis that may deal with variables that vary on differing spatial scales, such as porewater chemistry and organism abundance. If we were to average up to the largest scale (plots in this analysis), we would hide the variance of the porewater chemistry that may be relevant and could be accounted for in a regression analysis. Secondly, standard ANOVA is simply a special case of regression, in which measures of a dependent variable are assigned to an ordered categorical independent variable. The determination 
of a significant slope in such a regression analysis (ANOVA) is the equivalent of a significant treatment effect in a 1-way ANOVA. Although our approach is non-traditional, we feel the results provide considerable insight into the data in spite of the limitations of such a post hoc exploratory analysis.

The first series of post hoc exploratory analyses consisted of simple linear regressions of each chemical parameter versus organism density for each species (as determined by surface features). The second series of post hoc exploratory analyses contained multiple linear regressions using each chemical parameter versus organism density plus a species overlap index (Schoener 1970). Species overlap was calculated by a modification of Schoener's index (1970):

$$
\text { Overlap }=1-\left|p_{\mathrm{a}}-p_{\mathrm{t}}\right|
$$

where $p_{\mathrm{a}}$ is the proportion of arenicolids and $p_{\mathrm{t}}$ is the proportion of thalassinids. Application of a spatial overlap index would account for potential non-linearities in sediment geochemistry resulting from interactions among infauna. The closer in value the percentages of the 2 species are, the smaller the absolute difference between them and the closer to an overlap value of 1 . Overlap indices were arcsine transformed because they were proportions. After transformations, all parameters within the data set were standardized (or nondimensionalized), so each parameter had a mean of 0 and a standard deviation of 1 . These values have units of standard deviations and are called standardized deviates or Z-scores (Sokal \& Rolf 1969) and are calculated by:

$$
Z_{i}=\frac{X_{i}-\mu}{\sigma}
$$

where $X_{i}$ is the value of parameter $X$ and observation $i_{\text {, }}$ $\mu$ is the mean of the measured parameter, $\sigma$ is the standard deviation of the measured parameter, and $Z_{i}$ is the new standardized value of observation $i$. Regression parameters estimated using $Z$-scores can be directly compared to each other even if the original observations had different units. Differences in magnitude among the standardized regression parameters can be used to investigate which dependent variables (integrated porewater concentrations) are most influenced by density of arenicolids or thalassinids.

Assumptions (normality, homogeneity of variance) were checked, and potential outliers were examined using Cook's distance, DFBETA values, and Studentized residuals (Sokal \& Rolf 1969). In all cases, 1 to 3 outliers were detected, and in most cases it was the same observation for different solutes; therefore, those points were excluded from the regression as true outliers due to overly influential effects on parameter estimates.

\section{RESULTS}

\section{Organism abundance}

Results from the photographic surveys indicate the treatment assignments were appropriate and differences among plots remained relatively consistent with time (Table 1). No attempt was made to control or regulate the actual abundance of the 2 major taxa in the plots throughout the course of these experiments, because we wanted to minimize disturbance to the sediment fabric. Therefore, small changes in the relative abundances were expected due to natural variability associated with undisturbed habitats, and minor variability in surface features not directly related to abundance.

\section{Advection and diffusion experiments}

Results from the field measurements of tracer release from a gel diffuser indicate that advective flows are occurring in these sediments over a tidal cycle. Measurable fluorescein concentrations were found $1 \mathrm{~cm}$ from the gel source toward the mouth of

Table 1. Density of surface features per square meter (mean \pm SD) from photographic surveys of experimental plots for the 3 blocks and for 2 of the 3 experiment dates. July values correspond to the fluorescein-loss experiments, and the August values correspond to the porewater peeper experiments. Values represent number of fecal mounds (arenicolids, Abarenicola pacifica) and burrow openings (thalassinids, Upogebia pugettensis and Neotrypaea californiensis). The last column is the ratio of fecal mounds to burrow openings

\begin{tabular}{|c|c|c|c|c|}
\hline \multirow{2}{*}{$\begin{array}{l}\text { Date } \\
\text { Plot }\end{array}$} & \multirow[t]{2}{*}{ Block } & \multicolumn{3}{|c|}{- Surface features } \\
\hline & & Arenicolid & Thalassinid & Ratio \\
\hline \multicolumn{5}{|l|}{ July } \\
\hline \multirow[t]{3}{*}{ Arenicolid } & I & $49.33 \pm 7.42$ & $2.66 \pm 1.33$ & 18.54 \\
\hline & II & $70.66 \pm 9.61$ & $16.00 \pm 4.00$ & 4.41 \\
\hline & III & $36.00 \pm 6.92$ & $12.00 \pm 0.00$ & 3.00 \\
\hline \multirow[t]{3}{*}{ Mixed } & I & $37.33 \pm 2.66$ & $21.33 \pm 4.80$ & 1.75 \\
\hline & II & $20.00 \pm 6.11$ & $50.66 \pm 5.81$ & 0.39 \\
\hline & III & $21.33 \pm 3.52$ & $54.66 \pm 2.66$ & 0.39 \\
\hline \multirow{3}{*}{ Thalassinid } & I & $2.00 \pm 2.00$ & $34.00 \pm 6.00$ & 0.05 \\
\hline & II & $2.66 \pm 1.33$ & $61.33 \pm 9.61$ & 0.04 \\
\hline & III & $2.66 \pm 1.33$ & $62.66 \pm 8.11$ & 0.04 \\
\hline \multicolumn{5}{|l|}{ August } \\
\hline \multirow[t]{3}{*}{ Arenicolid } & I & $74.66 \pm 10.41$ & $18.66 \pm 2.66$ & 4.00 \\
\hline & II & $81.33 \pm 3.52$ & $25.33 \pm 9.33$ & 3.21 \\
\hline & III & $37.33 \pm 3.52$ & $28.00 \pm 4.00$ & 1.33 \\
\hline \multirow[t]{3}{*}{ Mixed } & $\mathrm{I}$ & $50.00 \pm 10.00$ & $28.00 \pm 4.00$ & 1.78 \\
\hline & II & $25.33 \pm 4.80$ & $50.66 \pm 10.41$ & 0.50 \\
\hline & III & $36.00 \pm 4.00$ & $58.66 \pm 3.52$ & 0.61 \\
\hline \multirow[t]{3}{*}{ Thalassinid } & I & $1.33 \pm 1.33$ & $65.33 \pm 11.85$ & 0.02 \\
\hline & II & $9.33 \pm 1.33$ & $74.66 \pm 13.13$ & 0.12 \\
\hline & III & $6.66 \pm 6.66$ & $48.00 \pm 6.92$ & 0.13 \\
\hline
\end{tabular}
for each plot 
the bay and slightly down slope $1 \mathrm{~h}$ and $45 \mathrm{~min}$ from the time of insertion, with a maximum $\left(75 \mathrm{\mu g} \mathrm{ml}^{-1}\right)$ occurring at $3 \mathrm{~h}$ and $45 \mathrm{~min}$ from gel insertion (Fig. 1). On the opposite side of the gel, maximum fluorescein concentrations at $1 \mathrm{~cm}$ distance reached a peak of only $\sim 2 \mu \mathrm{g} \mathrm{ml}^{-1}$ (data not shown). Thus, transport was asymmetric and rapid, likely due to advective processes associated with pressure gradients generated during drainage of the tidal flat. A concern of extracting porewater samples is the possibility of inducing transport via the removal of porewater. Although we cannot unequivocally dismiss some sampling effect of porewater extraction, the directionality of the measured transport is suggestive of advection. The missing section of the curve in Fig. 1 ( $4 \mathrm{~h}$ and 45 min from time of gel insertion) was due to little to no extractable porewater in the sediments at $5 \mathrm{~cm}$ depth. Three days subsequent to the gel insertion, porewater samples were again taken at $5 \mathrm{~cm}$ depth along the same transect as the first sample set (Fig. 2). Results confirm a similar pattern of asymmetrical concentration gradients.

A comparison of tracer concentration and transport time in the field to that obtained in the laboratory diffusion experiments confirms the occurrence of advective porewater movement in these sediments. Compared to field data $\left(\sim 80 \mu \mathrm{g} \mathrm{ml}^{-1}\right.$ at $1 \mathrm{~cm}$ after $\left.0.17 \mathrm{~d}\right)$, a similar concentration in the diffusion experiment was

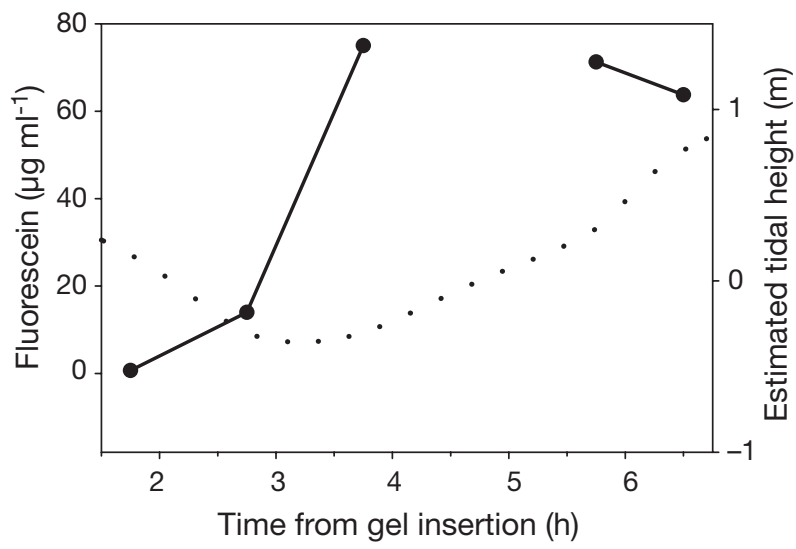

Fig. 1. Results from preliminary studies of porewater advection in False Bay sediments. Left $y$-axis shows fluorescein concentration (solid line) at $1 \mathrm{~cm}$ distance from the gel edge, toward the mouth of the bay, at $5 \mathrm{~cm}$ depth in the sediment. The $x$-axis is the time from gel insertion into the sediment. The broken section of the solid line corresponds to the sampling period when no porewater could be extracted from the sediment. Right $y$-axis shows estimated tidal height (dotted line) in False Bay in meters, based on observations and predicted tides in Friday Harbor. The directionality in concentration away from the gel plug down slope and not up indicates the importance of tidally generated pressure gradients in facilitating porewater advection

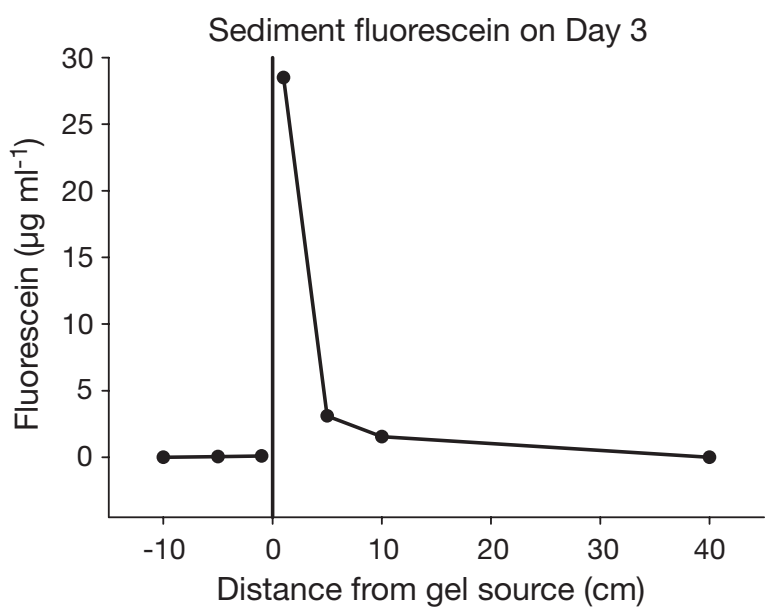

Fig. 2. Spatial transect showing fluorescein concentration at $5 \mathrm{~cm}$ depth on 26 May 2004, 3 d after the gel was inserted. The peak at $1 \mathrm{~cm}$ illustrates the effect of tidally induced pressure gradients on porewater movement and indicates directional (advective) transport. The solid vertical line at $x=0$ represents the location of the fluorescein-impregnated gel

found between $10 \mathrm{~d}\left(5.50 \mu \mathrm{g} \mathrm{ml}^{-1}\right.$ at $\left.1.5 \mathrm{~cm}\right)$ and $18 \mathrm{~d}$ (95.00 $\mu \mathrm{g} \mathrm{ml}^{-1}$ at $1.5 \mathrm{~cm}$ ) (Fig. 3). The difference in time and concentration between advection field experiments and diffusion experiments indicates that advective processes have substantial impacts on porewater transport in this habitat.

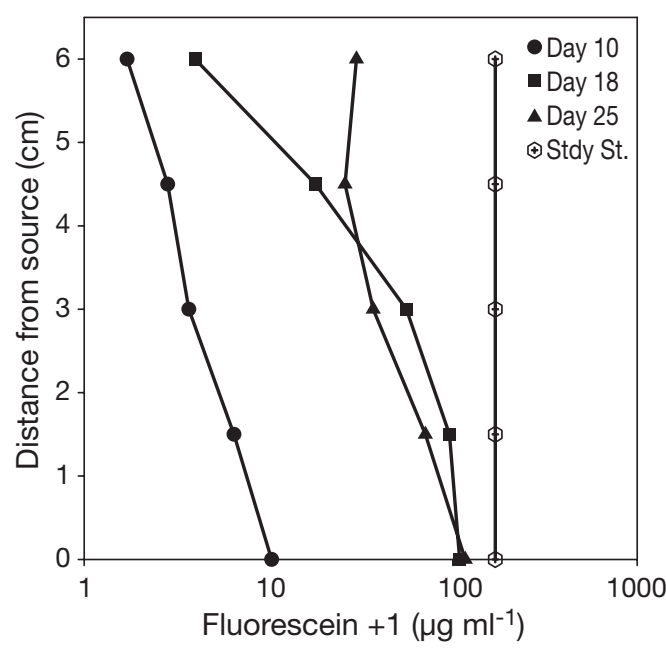

Fig. 3. Time series of fluorescein concentration profiles obtained from diffusion experiment in a controlled sediment tower with no advective transport. The profiles refer to time from initiation of the experiment. The vertical line is the theoretical profile at steady state (Stdy St.), assuming no loss of tracer. This profile was calculated based on the known concentration of tracer in a given volume of gel, volume of sediment and water in the column overlying the gel, and a representative porosity of the sediments in the experiments. Depth 0 is the depth adjacent to the acrylamide gel source 


\section{Fluorescein-loss experiments}

The recovery of the fluorescein-impregnated gels was not completely efficient. For each treatment, there should have been a total of 30 observations (5 surface and 5 deep gel sections per plot in each of 3 blocks). The actual recoverable gel samples for each treatment were 23, 15, 25 for the arenicolid, mixed, and thalassinid treatments, respectively. Thus, the degrees of freedom were relatively balanced between the arenicolid and thalassinid treatments, but the mixed treatment had fewer observations.

In spite of these difficulties, significant differences were found in the fluorescein-loss data $(\mathrm{p}<0.0001$, $\left.F_{2,58.7}=14.03\right)$. Fluorescein loss was higher in the arenicolid plots relative to the thalassinid and mixed plots, suggesting that porewater transport was highest in arenicolid regions. No significant effect of depth $(\mathrm{p}=$ $\left.0.2480, F_{1,57}=1.36\right)$ or block $\left(\mathrm{p}=0.3018, F_{2,57}=1.22\right)$ was found; therefore, the data were pooled and a 1-way ANOVA was conducted with block and depth as covariates. Once again, a significant treatment effect was found, with the arenicolid plots showing significantly less fluorescein remaining in the gels relative to the mixed ( $\left.\mathrm{p}=0.0049, t_{59.5}=3.28\right)$ and thalassinid plots $\left(p<0.0001, t_{57.6}=5.19\right)$, respectively. No significant difference was found between the mixed and thalassinid plots ( $p=0.5368, t_{59.4}=1.07$ ) (Fig. 4). These differences in fluorescein loss suggest that macrofaunal species composition is an important regulator of the extent of advective transport in permeable sediments. In particular, the arenicolids appear to be greater facilitators of advective transport relative to thalassinids. The lack of difference between deep $(\sim 8 \mathrm{~cm})$ and surface $(\sim 2 \mathrm{~cm})$ sections of the gel also indicate that these differences are not driven by organism effects on surface topography. Surface topography-driven flows tend to have shallow (3 to $5 \mathrm{~cm}$ ) penetration into the sediment column (e.g. Huettel et al. 1998).

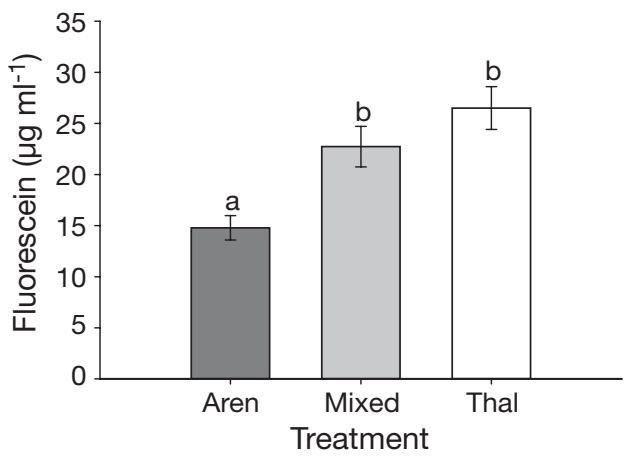

Fig. 4. Mean values $( \pm 1 \mathrm{SE})$ of fluorescein remaining in the gels for each treatment: arenicolid (aren), mixed and thalassinid (thal). Data are pooled for block and depth as no significant effect was found for either factor. Common letters indicate no significant difference between treatments

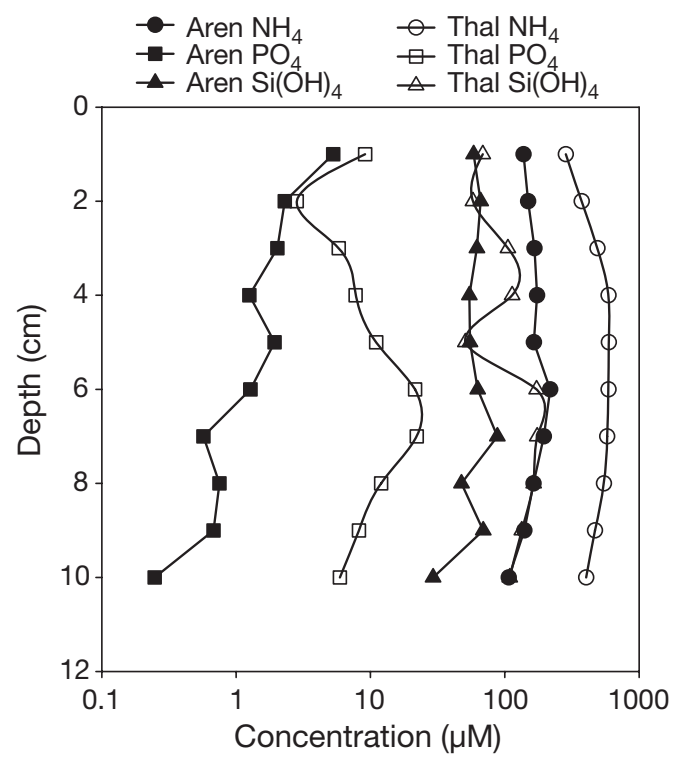

Fig. 5. Representative porewater profiles from 2 peeper deployments, 1 in an arenicolid (aren) plot (filled symbols) and 1 in a thalassinid (thal) plot (open symbols). Profiles of ammonium (circle), phosphate (square), and silicate (triangle) are shown

\section{Sediment porewater solutes}

The porewater peepers with acrylamide gels appeared to accurately record average porewater solute concentrations (Fig. 5), and corresponded well to direct porewater extractions at this site (Marinelli 1994, G. G. Waldbusser unpubl. data). Overall trends in the porewater data support differential rates of porewater transport associated with the different taxa in this study. In most cases the depth-integrated porewater concentrations were lower in the arenicolid plots relative to the thalassinid plots (Fig. 6). However, mixed plots showed considerable variation. For all solutes measured $\left(\mathrm{NH}_{4}{ }^{+}, \mathrm{PO}_{4}{ }^{3-}, \mathrm{Si}(\mathrm{OH})_{4}\right.$, dissolved inorganic carbon (DIC), alkalinity, and $\mathrm{pH}$ ), there was a significant treatment $\times$ block interaction in the 2-way ANOVA, making the interpretation of main treatment effects somewhat difficult (Table 2, Fig. 6). Closer examination of the data revealed that, in most cases, the interaction is driven by significant variation in the mixed treatment across blocks, perhaps associated with differences in abundance of the 2 organisms in these plots (Table 1). Because of the significant interaction terms in the original 2-way ANOVA, the possibility of density-dependent effects (Tables 1 \& 2), and the kinetic differences in solute reaction rates, post hoc regression analyses were conducted to explore relationships between organism density and porewater solute concentrations.

Linear regression results support the prediction of both density effects and kinetic effects. Parameter esti- 

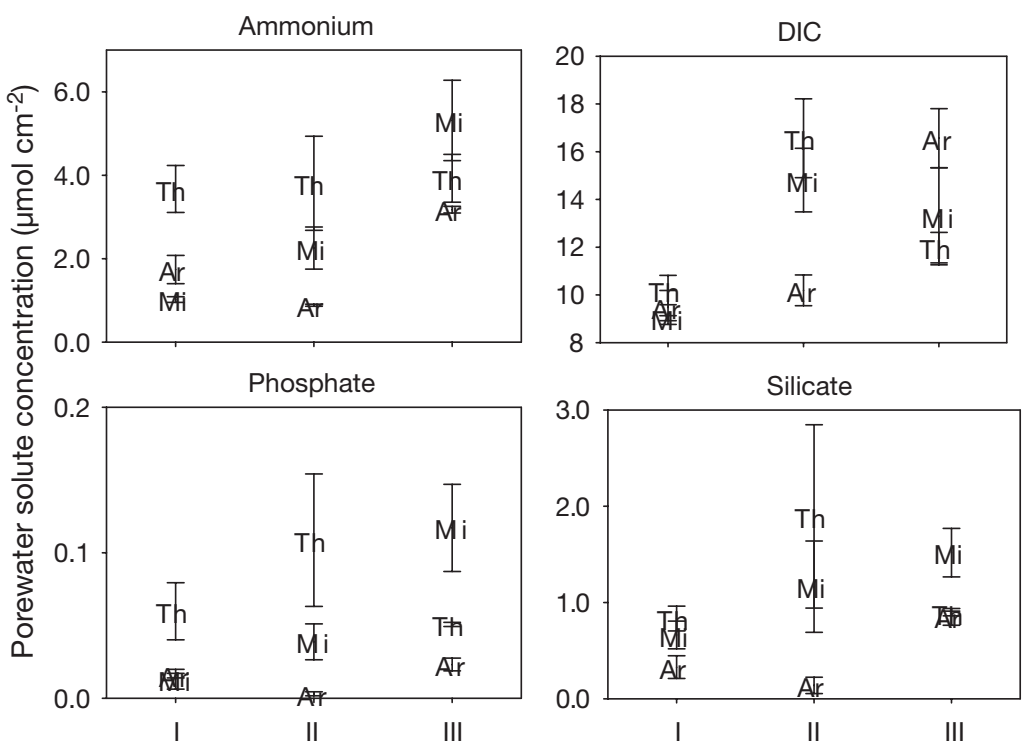

Fig. 6. Calculated least square means and standard errors for depth-integrated porewater profiles of each plot within each block (I to III). The $x$-axis refers to block number; the $y$-axis is the depth-integrated porewater solute concentration $\left(\mu \mathrm{mol} \mathrm{cm} \mathrm{cm}^{-2}\right)$. Note: scales are different. Ar: arenicolid; Mi: mixed; Th: thalassinid; DIC: dissolved inorganic carbon

mates suggest a stronger, negative effect of arenicolid density and a positive effect of thalassinid density, on ammonium and phosphate concentration relative to silicate concentration (Table 3). However, a pattern was detected in the distribution of the residuals for several of the simple linear regressions. Positive residuals were clustered about intermediate abundances (occurring generally in mixed plots), and negative residuals were found at the extremes (occurring generally in the single species plots). The presence of this non-random pattern in residuals, as well as failure of the data to meet the Shapiro-Wilks' test for normality, indicates that an additional variable may be needed in the regression analyses.

The results from multiple linear regressions, with overlap index, show better fits than the single linear models in most cases, as indicated by p-values and adjusted $\mathrm{R}^{2}$ of the 2 parameter model (Table 4 ). The

Table 2. F-values for the interaction terms in the 2-way ANOVA for block (blk) and treatment (trt) effects. The interaction is highly significant in all cases except silicate. DIC: dissolved inorganic carbon

\begin{tabular}{|lcrrr|}
\hline Solute & Effect & df & F-value & p-value \\
\hline Ammonium & blk $\times$ trt & 4,18 & 6.89 & 0.0015 \\
Phosphate & blk $\times$ trt & 4,18 & 6.57 & 0.0019 \\
Silicate & blk $\times$ trt & 4,18 & 4.16 & 0.0148 \\
DIC & blk $\times$ trt & 4,18 & 5.95 & 0.0031 \\
Alkalinity & blk $\times$ trt & 4,18 & 6.83 & 0.0016 \\
pH & blk $\times$ trt & 4,18 & 10.32 & 0.0002 \\
\hline
\end{tabular}

results also indicate a positive relationship between degree of species overlap and depth-integrated porewater concentrations of silicate, ammonium and DIC. This suggests that, while species identity and kinetic effects may contribute to overall porewater concentrations (Table 3), species interaction effects are also operative.

\section{Sediment parameters}

Granulometric analysis of composite sediment samples indicated very little difference in sediment grain size, porosity, and other measures among the experimental plots (Table 5). This argues against the hypothesis that the effects of the different organisms on porewater transport are related directly to changes in bulk sediment characteristics. In addition, organic $\mathrm{C}$ and $\mathrm{N}$ measures of surficial sediments among plots also show very little difference (Table 5).

Consistent with the bulk sediment analyses, the calculated permeability from each site shows no clear distinction as a function of experimental treatment, nor is it related to fluorescein-loss data (Figs. 4 \& 7). A simple linear regression between fluorescein remaining in the gels and the calculated permeability for the experimental plots was not significant $\left(\mathrm{p}=0.6038, F_{1,8}=0.30\right.$, $\left.\mathrm{R}^{2}=0.04\right)$. The porosity measures could be biased toward low values, since the sediment samples were taken at low tide and the drainage may have removed some of the water, though this should not affect among-site comparisons. However, the values calculated by the loss of weight via drying are very close to

Table 3. Results from the standardized simple linear regression analysis for effects of arenicolid and thalassinid density on integrated porewater solute concentrations. Analyses were performed on standardized data; therefore, the parameter estimates are directly comparable. Significance: ${ }^{*} p=0.05,{ }^{* *} p=$ 0.01 , and ${ }^{* * *} p=0.001$. Degrees of freedom for each analysis were between 27 and 24 and dependent on outlier detection and removal. Adj.: adjusted; DIC: dissolved inorganic carbon

\begin{tabular}{|c|c|c|c|c|}
\hline \multirow[t]{2}{*}{ Solute } & \multicolumn{2}{|c|}{ Arenicolid } & \multicolumn{2}{|c|}{ Thalassinid } \\
\hline & Estimate & Adj. $R^{2}$ & Estimate & Adj. $R^{2}$ \\
\hline Ammonium & $-0.698^{* * *}$ & 0.42 & $0.737^{* * *}$ & 0.49 \\
\hline Phosphate & $-0.532^{* * *}$ & 0.37 & $0.678^{* * *}$ & 0.59 \\
\hline Silicate & $-0.412^{* *}$ & 0.24 & $0.456^{* * *}$ & 0.39 \\
\hline DIC & $-0.505^{*}$ & 0.18 & $0.411^{*}$ & 0.14 \\
\hline Alkalinity & $-0.616^{* * *}$ & 0.38 & $0.829^{* * *}$ & 0.68 \\
\hline $\mathrm{pH}$ & -0.109 & -0.03 & 0.126 & -0.02 \\
\hline
\end{tabular}


Table 4. Results from the standardized multiple linear regression analysis inclusive of the overlap index and density effects on integrated porewater solute concentration. Parameter estimates for both density and overlap are presented for models run with arenicolid (Aren) density and thalassinid (Thal) density for each solute. Significance: ${ }^{*} p=0.05,{ }^{* *} p=0.01$, and ${ }^{* * *} \mathrm{p}=0.001$. Adj.: adjusted; DIC: dissolved inorganic carbon

\begin{tabular}{|lclllllr|}
\hline \multirow{2}{*}{ Solute } & \multicolumn{3}{c}{ Aren \& overlap } & \multicolumn{3}{c|}{ Thal \& overlap } \\
& Aren & Overlap & Adj. $\mathrm{R}^{2}$ & \multicolumn{2}{c}{ Thal } & Overlap & Adj. $\mathrm{R}^{2}$ \\
\hline Ammonium & $-0.972^{* * *}$ & $0.439^{*}$ & 0.50 & $0.901^{* * *}$ & 0.180 & 0.55 \\
Phosphate & $-0.684^{* * *}$ & 0.227 & 0.40 & $0.808^{* * *}$ & 0.183 & 0.60 \\
Silicate & $-0.783^{* * *}$ & $0.514^{* *}$ & 0.48 & $0.670^{* * *}$ & $0.329^{* *}$ & 0.58 \\
DIC & $-0.690^{* *}$ & $0.647^{* *}$ & 0.29 & $0.766^{* * *}$ & $0.643^{* * *}$ & 0.48 \\
Alkalinity & $-0.617^{* *}$ & 0.067 & 0.37 & $0.879^{* * *}$ & 0.114 & 0.68 \\
pH & 0.041 & 0.110 & -0.06 & 0.068 & 0.007 & -0.08 \\
\hline
\end{tabular}

milieu of marine sediments requires investigation of geochemical and physical processes in concert with biological characterization. Geochemical parameters such as organic matter input and reaction rate kinetics, physical parameters such as boundary layer interactions, and sediment granulometry all interact with organism characteristics (behavior, activity rates) and community level processes (density dependence) to determine the ecological landscape. Integration of these features over various scales in space and time determine the emergent ecosystem function.

earlier porosity measures made in the same area by using direct measurements of changes in volume of dried sediment added to known volumes of water (G. G. Waldbusser unpubl. data).

Results of the measured permeability using the falling-head permeameter experiments of intact sediment cores taken from Block I showed the following coefficients of permeability: arenicolid $\left(26.49 \mathrm{~cm} \mathrm{~h}^{-1}\right)$, mixed (18.55 $\left.\mathrm{cm} \mathrm{h}^{-1}\right)$, and thalassinid $\left(23.60 \mathrm{~cm} \mathrm{~h}^{-1}\right)$. As noted above, these values were based on 1 core from each site and, therefore, do not capture the extent of variability within the experimental plots. Qualitative comparison of the calculated permeability (Fig. 7) and the measured permeability (above) show similar patterns in the values between arenicolid and thalassinid plots, but not in the mixed plot.

\section{DISCUSSION}

To understand the effect of biodiversity and community structure on system function in benthic environments, it is important to adopt a mechanistic approach that includes both organisms and processes (Bolam et al. 2002, Reise 2002, Lohrer et al. 2004). The complex
The results from the present study underscore the need for an integrative approach to studies of advectively permeable sediments, an environment that is prominent and biogeochemically significant in coastal and continental shelf habitats (Jahnke et al. 2000,

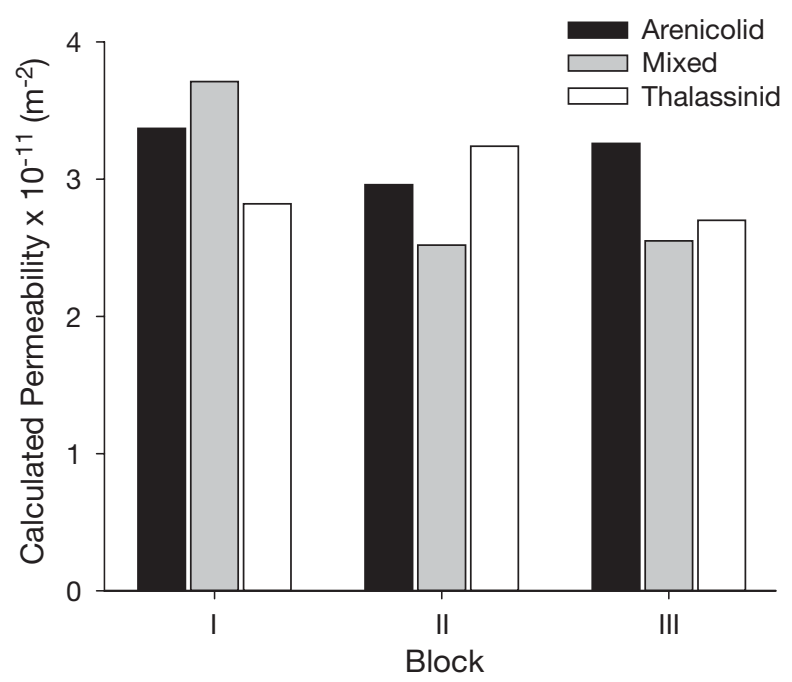

Fig. 7. Calculated permeability by the Rumpf-Gupte equation for composite samples from each plot among blocks

Table 5. Sediment characteristics from composite samples of all the experimental plots, blocks (I, II, III), and treatments (M: mixed; A: arenicolid; T: thalassinid). Organic carbon and nitrogen are from replicate samples (3) within each plot (in \% w/w, $\pm 1 \mathrm{SD})$; standard deviations in organic nitrogen within site were $<0.00$. Categorical classification of sediments is given in the right-hand column (from Folk \& Ward 1957)

\begin{tabular}{|lrrrrrrrrrr|}
\hline Measure & I/M & I/A & I/T & II/M & II/A & II/T & III/M & III/A & III/T & Classification \\
\hline Grain (phi) & 2.88 & 2.88 & 2.93 & 2.93 & 2.71 & 2.83 & 3.11 & 2.99 & 3.07 & Fine sands \\
Sorting & 1.78 & 1.78 & 1.78 & 1.91 & 1.77 & 1.84 & 1.88 & 1.79 & 1.86 & Poorly sorted \\
Skewness & 0.00 & 0.01 & 0.01 & -0.02 & -0.02 & -0.01 & 0.01 & 0.01 & 0.02 & Symmetrical \\
Kurtosis & 1.11 & 1.11 & 1.08 & 1.05 & 1.08 & 1.07 & 1.08 & 1.07 & 1.09 & Mesokurtic \\
Porosity & 0.44 & 0.43 & 0.42 & 0.42 & 0.41 & 0.43 & 0.44 & 0.44 & 0.44 & \\
Organic C & 0.17 & 0.21 & 0.21 & 0.19 & 0.18 & 0.21 & 0.18 & 0.20 & 0.17 & \\
Org. C SD & \pm 0.01 & \pm 0.09 & \pm 0.02 & \pm 0.01 & \pm 0.01 & \pm 0.03 & \pm 0.01 & \pm 0.06 & \pm 0.02 & 0.02 \\
Organic N & 0.02 & 0.02 & 0.03 & 0.03 & 0.02 & 0.03 & 0.02 & 0.02 & 0.02 \\
\hline
\end{tabular}


2003, Rocha 2000, Rusch et al. 2001, Reimers et al. 2004). Such environments are characterized by porous sediments with low standing stock but high throughput of organic material and rapid rates of biogeochemical cycling and porewater exchange (Marinelli et al. 1998). We utilized the natural variability of dominant infauna in this permeable sediment habitat to more accurately represent the role of functionally different infauna and their interaction on ecosystem-type processes over previous manipulated experimental systems. An important concern in using unmanipulated naturally occurring infaunal communities is the potential for other larger-scale correlated parameters to be the drivers of among-treatment variability. The spatial proximity of plots, lack of differences in granulometry, and lack of any noticeable pattern in species distributions across the flat all indicate that species distributions (on the scale of the experiment) are not the result of larger-scale physical factors that may be confounding treatment effects. In other words, on our scales of measurement, the biology seems to be a causative agent, not responding to our measured parameters. We have shown that (1) functionally different macrofauna affect rates of porewater advection in permeable sediments, (2) the effects are not attributable to changes in average vertically integrated measures of sediment granulometry or other plot-specific characteristics that may be due to non-biological effects, (3) species interactions may further complicate the advective environment and the resulting diagenetic processes, and (4) species effects on geochemistry vary according to reaction rate kinetics of particular spoutes (described below).

Previous studies of infaunal effects on permeable sediments have emphasized surface processes related to topographic variation or sediment disturbance (Huettel et al. 1998, D'Andrea et al. 2002). This study emphasizes below-surface processes, including species-specific effects and species interactions. Although D'Andrea et al. (2002) also examined below-surface effects on sediment dynamics, our results suggest a different suite of mechanisms for organism effects on transport. In their study, thalassinids were found to increase organic matter reaction rates in closer proximity to burrows and to increase flushing rates at depth in the less-permanent sections of the burrow. Our study emphasizes the effects of functionally different species' burrow morphology and feeding behavior on below-surface advective transport. In addition, belowsurface species interactions appear to promote nonlinear relationships between infauna and sediment geochemistry that may form the basis for 'biodiversity effects' in sedimentary habitats (Waldbusser et al. 2004).

Surface processes that generate porewater advection include surface gravity waves in shallow water and interactions between surface topography and fluid flow fields (Huettel \& Gust 1992, Reimers et al. 2004). Both of these mechanisms are present at False Bay. However, the lack of difference between near surface and deep sections of the gel indicates that transport does not decrease with depth (across the interval we studied, surface to $\sim 10 \mathrm{~cm}$ ), as is often the case with surface processes affecting the upper $5 \mathrm{~cm}$ of the sediment column (Huettel et al. 1998). Examination of the photographic data found roughly 5 to 7 sand ripple peaks in the sediment surface across a $50 \mathrm{~cm}$ transect, corresponding to an average ripple wave length of roughly $10 \mathrm{~cm}$. The shape of the ripples indicates that the dominant flow direction during the flood tide is counter to the direction of the tracer gradient after $3 \mathrm{~d}$ of gel deployment (Fig. 2). Observations made during the gel diffuser experiments found that overlying water covers the sediment faster than it can percolate through it horizontally due to the pressure gradient. Therefore, the lack of a depth effect on fluorescein loss, the size and shape of the sediment ripples, and the observed direction of tracer transport all indicate that pressure gradients associated with tidal drainage and flooding, coupled with fine-scale variation driven by organisms, are likely the dominant mechanisms driving patterns of advective exchange. Other sources of pressure differentials, such as boundary interactions, surface gravity waves, and thermal convection, may also contribute to rapid transport within these sediments.

The fluorescein-loss experiments and sedimentpermeability analyses suggest that fine-scale measurements and consideration of organism behavior may be necessary to capture the mechanisms that promote the observed species differences in advective flow. Finer-scale features, such as burrow wall composition or channels associated with feeding and sediment fluffing, are likely to be extremely important in either blocking or facilitating flow; these are not captured by traditional bulk analyses. More advanced measures such as high-resolution CT Scan or ultrasound may be required to reveal these features and their significance to transport in coastal sediments (Solan et al. 2003, Wethey \& Woodin 2005). Therefore, based on our findings and many prior studies, we must look to organism-specific attributes for discerning the mechanism(s) behind the differences we found.

We hypothesize that the higher flushing rates found in the arenicolid plots compared to the thalassinid plots probably relate to differences in motility, feeding, and burrow construction between the 2 dominant taxa. During feeding, arenicolids fluidize sediment at the base of the feeding area and create localized hot spots of vertical advective throughput (Huettel 1990, Riisgård \& Banta 1998, Timmermann et al. 2002, 2003). 
In addition, recent ultrasound measurements (Wethey \& Woodin 2005) indicate advective pumping of the area immediately below and surrounding the burrow opening (upper 2 to $3 \mathrm{~cm}$ ) during near hourly defecation events. The effects of vertical advective displacement of particles and fluid by arenicolids may directly or indirectly influence the rate of horizontal transport due to pressure gradients generated through tidal sediment saturation and draining. Arenicolids also appear to move reasonably frequently (Krager \& Woodin 1993), perhaps in response to food patches (S. A. Woodin unpubl. data), ammonium concentrations (R. L. Marinelli unpubl. data), or in relation to life stage (Linton \& Taghon 2000). Thus, sediment fluidization and movement may link resources and life history with advective transport. The potential effect of these linkages and their relation to microbial activity, benthic primary production, and nutrient cycling has been noted by Jumars et al. (1990), but little to no empirical evidence exists to verify or nullify these ideas.

In contrast to arenicolids, thalassinids create large feeding galleries where they feed directly in the sediment within the gallery (Neotrypaea californiensis), or filter feed by pumping overlying water (Upogebia pugettensis). Some investigators have suggested that microbes yielded through 'gardening' are also an important food source for thalassinids (Jumars et al. 1990, Kinoshita et al. 2003). Thalassinid species are often observed to eject fines (MacGinite 1930, Suchanek 1983, Posey et al. 1991, Pinn et al. 1998, Feldman et al. 2000) or have high pumping rates of burrow water compared to the physical processes of tidal exchange (Dworschak 1981); therefore, it should be expected that they would, in turn, increase the transport rates of porewater within sediments and affect rates of organic matter remineralization (Ziebis et al. 1996, D'Andrea et al. 2002). In contrast to prior studies, our study found no difference in grain size distributions (Table 5), and transport rates were slower in thalassinid areas compared to arenicolid areas (Fig. 4), though true organism-free control plots were lacking. It should also be noted that surface features often found in association with thalassinid burrows were lacking from the experimental area. The redistribution of the fine-grained sediment during tidal flows or the dominance of the filter-feeding $U$. pugettensis (Griffis \& Suchanek 1991) are 2 potential reasons sediment mounds associated with burrow openings were not found. Observations from various burrows around the experimental site found that the upper portions of the thalassinid burrows are thickly lined with clay and appear to be impermeable. In addition, pressure sensors placed near thalassinid burrows indicate little to no signal associated with feeding or movement, suggesting the walls are extremely thick relative to arenicolid burrow walls (D. S. Wethey \& S. A. Woodin unpubl. data). We suggest that thalassinids in False Bay actually decrease bulk permeability through creation of near-solid structures that serve to interrupt flow. Analogous to pipes running through the sediment column, these near-solid structures may interfere with arenicolid feeding via inhibition of sediment fluidization and subduction.

The use of organism density in our analyses of porewater solutes coupled with kinetic differences among the solutes provides a mechanistic basis for interpreting the complex results obtained. The significant block by treatment interactions in the original 2-way ANOVA of porewater data are not surprising, given the differences in relative densities of the 2 experimental organisms across the mixed treatments (Table 1). Prior investigations of benthic community dynamics and sedimentary functioning used biomass to account for bulk organism effects (Emmerson et al. 2001, Bolam et al. 2002), but measures of abundance more explicitly account for the effects of burrow surface area on sediment-seawater exchange (Aller 1980) and individual interactions (Marinelli 1994). Furthermore, recent investigators have found density-dependent effects on sediment chemistry (Gilbert et al. 2003, Marinelli \& Williams 2003, Lohrer et al. 2004), driven in part by kinetic effects. We predicted that, based on kinetics arguments (Aller 1980, Marinelli 1992, Boudreau \& Marinelli 1994), ammonium and phosphate should be most sensitive to advective processes facilitated by infauna and exhibit strong density dependence. Both ammonium and phosphate are produced by organic matter decomposition, and production is not affected by porewater concentration. Such solutes are highly sensitive to the degree of biologically mediated transport in sediments. Phosphate also is readily adsorbed to particles in the presence of oxygen, so rapid advection of oxic seawater is likely to further decrease phosphate concentrations in the porewater. Conversely, silica dissolution is abiotic, partly controlled by the degree of saturation, and less sensitive to biologically driven transport. Thus, differences in the effects of infauna on solute concentration may relate in part to interactions between density and reaction rate kinetics, as observed in the regression parameters (Tables $3 \& 4$ ).

The inclusion of the overlap parameter also resulted in better model fits, a more detectable density effect, and some congruence with the expected relationship between density, kinetics, and solute loss (Table 4). A possible mechanism behind the significant overlap effect may lie in our proposed interaction between arenicolids and thalassinids, where thalassinid burrows act as impermeable objects that restrict the feeding and fluidizing behaviors of the arenicolids. Posey 
et al. (1991), and references therein, have shown the negative effects of thalassinids on smaller macrofauna related to bioturbation and/or adult-larval interactions. Similar negative effects have been documented with arenicolid feeding and depositional burial of smaller macrofauna (Riisgård \& Banta 1998, and references therein). More importantly to the current study, we present a potential inhibition of arenicolid feeding by thalassinid burrows, linking organism behavior and transport mechanisms in sediments, possibly cascading into ecosystem functions such as nutrient cycling, microbial dynamics, and benthic primary production. Current models of advective transport include bulk sediment parameters and hydraulic pressure heads (Boudreau 1997), but do not reflect this level of complexity. Experiments incorporating the fine-scale measures of these processes are required if we are to incorporate biologically complex parameters into current models of elemental cycling in permeable sediments and into our evaluation of ecosystem services provided by coastal habitats.

Complex associations of the biological, chemical, and physical processes co-act to determine ecosystem function. Our findings illustrate the importance of behavior and ecological considerations in studies of sediment dynamics and, conversely, the importance of dynamics and processes in studies of biodiversity and ecosystem function. Developing predictive models of the effects that species loss has on the functioning of coastal systems requires a mechanistic, process-based approach. Given the broad scope of anthropogenic impacts on many coastal ecosystems and the well documented changes in the structure of the coastal marine biological community (Levin et al. 2001), integrative studies are critical to understanding and maintaining living resources.

Acknowledgements. Comments made by 4 anonymous reviews were constructive and helpful in improving this manuscript. This research was supported by a Maryland Sea Grant Graduate Research Fellowship (\#NA16RG2207) and an Alan Kohn Fellowship from Friday Harbor Laboratories to G.G.W. and by grants from the Office of Naval Research and Maryland Sea Grant (\#SA07-5-28051Q) to R.L.M. We thank the administration, staff, and faculty of Friday Harbor Laboratories for their unbridled help and support, as well as the many friends and colleagues who made the stay memorable. We also thank S. A. Woodin and D. S. Wethey who contributed both intellectually and logistically. S. E. Kolesar provided support during G.G.W.'s stay at Friday Harbor and made thoughtful comments on earlier versions of this manuscript. This research has been conducted by G.G.W. as partial fulfillment of requirements for a $\mathrm{PhD}$ from the University of Maryland. The statements, findings, conclusions, and recommendations are those of G.G.W. and R.L.M. and do not necessarily reflect the views of Maryland Sea Grant, the National Oceanic and Atmospheric Administration, or the US Dept. of Commerce.

\section{LITERATURE CITED}

Aller RC (1980) Quantifying solute distributions in the bioturbated zone of marine sediments by defining an average microenvironment. Geochim Cosmochim Acta 44: 1955-1965

Biles CL, Solan M, Isaksson I, Paterson DM, Emes C, Raffaelli DG (2003) Flow modifies the effect of biodiversity on ecosystem function: an in situ study of estuarine sediments. J Exp Mar Biol Ecol 285/286:165-177

Bolam S, Fernandes T, Huxham M (2002) Diversity, biomass, and ecosystem processes in the marine benthos. Ecol Monogr 72:599-615

Boudreau BP (1984) On the equivalence of nonlocal and radial-diffusion models for porewater irrigation. J Mar Res 42:731-735

Boudreau BP (1997) Diagenetic models and their implementation. Springer-Verlag, Berlin

Boudreau BP, Marinelli RL (1994) A modeling study of discontinuous biological irrigation. J Mar Res 52:947-968

Brenchley GA (1981) Disturbance and community structure: an experimental study of bioturbation in marine softbottom environments. J Mar Res 9:767-790

Browne KA, Zimmer RK (2001) Controlled field release of a waterborne chemical signal stimulates planktonic larvae to settle. Biol Bull (Woods Hole) 200:87-91

Canfield DE, Jørgensen BB, Fossing H, Glud R and 6 others (1993a) Pathways of organic carbon oxidation in three continental margin sediments. Mar Geol 113:27-40

Canfield DE, Thamdrup B, Hansen JW (1993b) The anaerobic degradation of organic matter in Danish coastal sediments: iron reduction, manganese reduction, and sulfate reduction. Geochim Cosmochim Acta 57:3867-3883

Coelho VR, Cooper RA, Rodrigues SA (2000) Burrow morphology and behavior of the mud shrimp Upogebia omissa (Decapoda: Thalassinidea: Upogebiidae). Mar Ecol Prog Ser 200:229-240

D'Andrea AF, Aller RC, Lopez GR (2002) Organic matter flux and reactivity on a South Carolina sandflat: the impacts of porewater advection and macrobiological structures. Limnol Oceanogr 47:1056-1070

D'Andrea AF, Lopez GR, Aller RC (2004) Rapid physical and biological particle mixing on an intertidal sandflat. J Mar Res 62:67-92

de Beer D, Wenzhöfer F, Ferdelman TG, Boehme SE and 5 others (2005) Transport and mineralization rates in North Sea sandy intertidal sediments, Sylt-Rømø Basin, Wadden Sea. Limnol Oceanogr 50:113-127

Dumbauld BR, Armstrong DA, Feldman KL (1996) Lifehistory characteristics of two sympatric thalassinidean shrimps, Neotrypaea californiensis and Upogebia pugettensis, with implications for oyster culture. J Crustac Biol 16:689-708

Dworschak PC (1981) The pumping rates of burrowing shrimp Upogebia pusilla (Petagna) (Decapoda: Thalassinidea). J Exp Mar Biol Ecol 52:25-35

Eaton AD, Clesceri LS, Greenberg AE (1995) Standard methods for the examination of water and wastewater, 19th edn. American Public Health Association, Washington, DC

Eckman JE (1983) Hydrodynamic processes affecting benthic recruitment. Limnol Oceanogr 28:241-257

Eckman JE (1996) Closing the larval loop: linking larval ecology to the population dynamics of marine benthic invertebrates. J Exp Mar Biol Ecol 200:207-237

Emmerson MC, Solan M, Emes C, Paterson DM, Raffaelli DG (2001) Consistent patterns and the idiosyncratic effects of biodiversity in marine ecosystems. Nature 411:73-77 
Engstrom S, Marinelli RL (2005) Recruitment responses of benthic infauna to manipulated sediment geochemical properties in natural flows. J Mar Res 63:407-436

Feldman KL, Armstrong DA, Dumbauld BR, DeWitt TH, Doty DC (2000) Oysters, crabs, and burrowing shrimp: review of an environmental conflict over aquatic resources and pesticide use in Washington State's (USA) coastal estuaries. Estuaries 23:141-176

Folk RL, Ward WC (1957) Brazos River bar: a study of significance of grain size parameters. J Sediment Petrol 27:3-26

Gilbert F, Aller RC, Hulth S (2003) The influence of macrofaunal burrow spacing and diffusive scaling on sedimentary nitrification and denitrification: an experimental simulation and model approach. J Mar Res 61:101-125

Gray H (1958) Suggested method of test for permeability of porous granular materials by the falling-head permeameter. In: Procedures for testing soils. American Society for Testing Materials, Philadelphia, PA, p 253-255

Griffis RB, Suchanek TH (1991) A model of burrow architecture and trophic modes in thalassinidean shrimp (Decapoda: Thalassinidea). Mar Ecol Prog Ser 79:171-183

Guinasso NL, Schink DR (1975) Quantitative estimates of biological mixing rates in abyssal sediments. J Geophys Res 80:3032-3043

Hesslein RH (1976) An in situ sampler for close interval pore water studies. Limnol Oceanogr 21:912-914

Hobson KD (1967) The feeding and ecology of two North Pacific Abarenicola species (Abarenicolidae, Polychaete). Biol Bull (Woods Hole) 33:343-354

Huettel M (1990) Influence of the lugworm Arenicola marina on porewater nutrient profiles of sand flat sediments. Mar Ecol Prog Ser 62:241-248

Huettel M, Gust G (1992) Impact of bioroughness on interfacial solute exchange in permeable sediments. Mar Ecol Prog Ser 89:253-267

Huettel M, Webster IT (2001) Porewater flow in permeable sediments. In: Boudreau BP, Jørgensen BB (eds) The benthic boundary layer: transport processes and biogeochemistry. Oxford University Press, New York, p 144-179

Huettel M, Ziebis W, Forester S, Luther GW III (1998) Advective transport affecting metal and nutrient distributions and interfacial fluxes in permeable sediments. Geochim Cosmochim Acta 62:613-631

Jahnke RA, Jahnke DP (2000) Rates of C, N, P, and Si recycling and denitrification at the US mid-Atlantic continental slope depocenter. Deep-Sea Res I 47:1405-1428

Jahnke RA, Nelson JR, Marinelli RL, Eckman JE (2000) Benthic flux of biogenic elements on the southeastern US continental shelf: influence of pore water advective transport and benthic microalgae. Cont Shelf Res 20:109-127

Jahnke RA, Alexander CR, Kostka JE (2003) Advective pore water input of nutrients to the Satilla River estuary, Georgia, USA. Estuar Coast Shelf Sci 56:641-653

Jumars PA, Mayer LM, Deming JW, Baross JA, Wheatcroft RA (1990) Deep-sea deposit-feeding strategies suggested by environmental and feeding constraints. Philos Trans R Soc Lond 331:85-101

Kinoshita K, Wada M, Kogure K, Furota T (2003) Mud shrimp burrows as dynamic traps and processors of tidal-flat materials. Mar Ecol Prog Ser 247:159-164

Kinzing AP, Pacala SW, Tilman D (2001) The functional consequences of biodiversity. Princeton University Press, Princeton, NJ

Koroleff F (1976) Determination of $\mathrm{NH}_{4}-\mathrm{N}$. In: Grasshoff K (ed) Methods of seawater analysis. Verlag Chemie, Weinheim, p 127-133

Krager CD, Woodin SA (1993) Spatial persistence and sedi- ment disturbance of an arenicolid polychaete. Limnol Oceanogr 38:509-520

Kristensen E, Jensen MH, Andersen TK (1985) The impact of polychaete (Nereis virens Sars) burrows on nitrification and nitrate reduction in estuarine sediments. J Exp Mar Biol Ecol 85:75-91

Levin L, Blair N, DeMaster D, Plaia G, Fornes W, Martin C, Thomas C (1997) Rapid subduction of organic matter by maldanid polychaetes on the North Carolina slope. J Mar Res 55:595-611

Levin LA, Boesch DF, Covich A, Dahm C and 8 others (2001) The function of marine critical transition zones and the importance of sediment biodiversity. Ecosystems 4: $430-451$

Linton DL, Taghon GL (2000) Feeding, growth, and fecundity of Abarenicola pacifica in relation to sediment organic concentration. J Exp Mar Biol Ecol 254:85-107

Lohrer AM, Thrush SF, Gibbs MM (2004) Bioturbators enhance ecosystem function through complex biogeochemical interactions. Nature 431:1092-1095

MacGinite GE (1930) The natural history of the mud shrimp Upogebia pugenttensis (Dana). Ann Mag Nat Hist 10: $36-47$

Marinelli RL (1992) Effects of polychaetes on silicate dynamics and fluxes in sediments: importance of species, animal activity and polychaete effects on benthic diatoms. J Mar Res 50:745-779

Marinelli RL (1994) Effects of burrow ventilation on activities of a terebellid polychaete and silicate removal from sediment pore waters. Limnol Oceanogr 39:303-317

Marinelli RL, Waldbusser GG (2005) Plant-animal-microbe interactions: closing the ecological loop. In: Kirstensen E, Haese RR, Kostka JE (eds) Interactions between macroand microorganisms in marine sediments. Coastal and Estuarine Studies, Vol 60. American Geophysical Union, Washington, DC, p 233-249

Marinelli RL, Williams TJ (2003) Evidence for density dependent effects of infauna on sediment biogeochemistry and benthic-pelagic coupling in nearshore systems. Estuar Coast Shelf Sci 57:179-192

Marinelli RL, Jahnke RA, Craven DB, Nelson JR, Eckman JE (1998) Sediment nutrient dynamics on the South Atlantic Bight continental shelf. Limnol Oceanogr 43:1305-1320

Mortimer RJG, Krom MD, Boyle DR, Nishir A (1999) Use of a high resolution porewater gel profiler to measure groundwater fluxes at an underwater saline seepage site in Lake Kinneret, Israel. Limnol Oceangr 44:1802-1809

Nickell LA, Atkinson RJA (1995) Functional morphology of burrows and trophic modes of three thalassinidean shrimp species, and a new approach to the classification of thalassinidean burrow morphology. Mar Ecol Prog Ser 128: 181-197

Pinn EH, James R, Atkinson A, Rogerson A (1998) Particle size selectivity and resource partitioning in five species of Thalassinidea (Crustacea: Decapoda). Mar Ecol Prog Ser 169:243-250

Posey MH, Dumbauld BR, Armstrong DA (1991) Effects of a burrowing mud shrimp, Upogebia pugettensis (Dana), on abundances of macro-infauna. J Exp Mar Biol Ecol 148: 283-294

Reise K (2002) Sediment mediated species interactions in coastal waters. J Sea Res 48:127-141

Reimers CE, Stecher HA III, Taghon GL, Fuller CM, Huettel M, Rusch A, Ryckelynck N, Wild C (2004) In situ measurements of advective solute transport in permeable shelf sands. Cont Shelf Sci 24:183-201

Riisgård HU, Banta GT (1998) Irrigation and deposit feeding 
by the lugworm Arenicola marina, characteristics and secondary effects on the environment. A review of current knowledge. Vie Milieu 48:243-257

Rocha C (2000) Density-driven convection during flooding of warm, permeable intertidal sediments: the ecological importance of the convective turnover pump. J Sea Res 43: $1-14$

Rusch A, Forster S, Huettel M (2001) Bacteria, diatoms and detritus in an intertidal sandflat subject to advective transport across the water-sediment interface. Biogeochemistry 55:1-27

Schoener TW (1970) Nonsynchronous spatial overlap of lizards in patchy habitats. Ecology 51:408-418

Sokal RR, Rohlf FJ (1969) Biometry. Freeman, San Francisco, CA

Solan M, Germano JD, Rhoads DC, Smith C and 11 others (2003) Towards a greater understanding of pattern, scale and process in marine benthic systems: a picture is worth a thousand words. J Exp Mar Biol Ecol 285/286:313-338

Strickland JDH, Parsons TR (1972) A practical handbook of seawater analysis. Fish Res Board Can. Bulletin 167

Suchanek TH (1983) Control of seagrass communities and sediment distribution by Callianassa (Crustacea, Thalassinidea) bioturbation. J Mar Res 41:281-298

Taghon GL (1988) The benefits and costs of deposit feeding in the polychaete Abarenicola pacifica. Limnol Oceanogr 33: 1166-1175

Taghon GL, Nowell ARM, Jumars PA (1980) Induction of suspension feeding in spionid polychaetes by high particulate

Editorial responsibility: Martin Solan (Guest Editor), Newburgh, UK fluxes. Science 210:562-564

Thamdrup B, Fossing H, Jørgensen BB (1994) Manganese, iron, and sulfur cycling in a coastal marine sediment, Aarhus Bay, Denmark. Geochim Cosmochim Acta 58: $5115-5129$

Timmermann K, Christensen JH, Banta GT (2002) Modeling of advective solute transport in sandy sediments inhabited by the lugworm Arenicola marina. J Mar Res 60:151-169

Timmermann K, Banta GT, Larsen J, Andersen O (2003) Modelling paticle and solute transport in sediments inhabited by Arenicola marina. Effects of pyrene on transport processes. Vie Milieu 53:187-200

Waldbusser GG, Marinelli RL, Whitlatch RB, Visscher PT (2004) The effects of infaunal biodiversity on biogeochemistry of coastal marine sediments. Limnol Oceanogr 49: 1482-1492

Wardle DA (1999) Is 'sampling effect' a problem for experiments investigating biodiversity-ecosystem function relationships? Oikos 87:403-407

Wethey DS, Woodin SA (2005) Infaunal hydraulics generate porewater pressure signals. Biol Bull 209:139-145

Widdicombe S, Austen MC (1998) Experimental evidence for the role of Brissopsis lyrifera (Forbes, 1841) as a critical species in the maintenance of benthic diversity and the modification of sediment chemistry. J Exp Mar Biol Ecol 228:241-255

Ziebis W, Forster S, Huettel M, Jørgensen BB (1996) Complex burrows of the mud shrimp Callianassa truncata and their geochemical impact on the sea bed. Nature 382:619-622

Submitted: December 15, 2004; Accepted: October 21, 2005 Proofs received from author(s): March 7, 2006 